\title{
A NOTE ON THE PARASITIC BEETLE, HORNIA MINUTIPENNIS RILEY ${ }^{1}$.
}

\author{
By PhIL RAU
}

Kirkwood, Mo.

In the Ecology of a Clay Bank ${ }^{2}$, (p. 236), I have already recorded that the parasitic beetle, Hornia minutipennis, was twice taken from the nests of the burrowing bee, Anthophora abrupta. Riley has named this species from beetles taken from the nests of this bee (sponsa=abrupta) collected in this region. Since the publication of the ecology paper, I have gathered a few meagre notes on the habits of this parasite, and since so little is known of its behavior, I beg leave to present them here.

It is well known that the beetle larvæ in the triungulin stage attach themselves to the pubescence of the bees and by this method are transported to the bees' nests, where they feed upon the bee larvæ and attain their maturity.

In 1925, on May 5 and 17, I found one female each time, walking about on the lumps of clay containing the nests of the Anthophora bees, which I had brought into the laboratory. Some time later, June 7, I found on the surface of the clay mass five distinct clusters of triunguli, which apparently had hatched from eggs which I had not noticed. These masses or colonies were separate groups, and the larvæ did not move about at this stage. However, when I came near or brushed them with bits of cotton or dead Anthophora bees, they readily attached themselves to fibers and hairs.

On another occasion a very small hole was discovered in one of the bee cells. Upon opening the cell, an adult female beetle was discovered inside; hence I assumed that the beetle had made the opening. In still another cell, where a hole of the same size was found, I removed a dead mother beetle and hundreds of living triunguli. Another

1Identified by Mr. E. A. Schwarz.

2Trans. Acad. Sci. St. Louis 25: 236-7, 1926. 
cell which I opened contained a fat female but no eggs or young; an additional cell (found open) contained the shedding skin of the mother and several live triunguli. My first thought was, upon finding the first small opening, that I had discovered the mother in the act of biting her way out. But upon finding in another cell, behind a similar hole, a dead mother and her live young, I began to suspect that the mother beetle does not leave the nest. This would indicate that one or two conditions must obtain; either fertilization must have taken place through the small aperture in the wall of the Anthophora cell, or the eggs of the Hornia must have hatched without fertilization. My present data are insufficient to give preference to either theory.

I doubt that locomotion by the adult is a factor in their dissemination; their wings are small and useless in flight, their legs are too weak for lengthy walks, and the body too heavy for either type of movement. I have, however, as already stated, seen two adults (in addition to the one recorded in the Ecology paper) slowly lumbering along the clods of earth containing cells of the anthophora bee, but these beetles probably had escaped from clods broken by me for observation.

The colonies of live triunguli discovered on June 7 were placed outdoors on the clay bank, among a weak colony of bees. They were watched for about ten days. During that time, all the colonies held together without any evidence of dissemination. They seemed to get along without food, unless they ate part of their own number, for the bank afforded them no means of subsistence. On June 25, more than two weeks after they had been placed out of doors, the colonies were still intact, although much reduced in size. However, some must have been moving about, for several were found dead in a nearby spider web.

The idea seems prevalent that the eggs hatch in the fall and the young hibernate. In this species, at least, the eggs are laid in the spring. One female, taken from a cell several years ago, laid many eggs in a vial in the spring. This corroborates Riley's statement that the eggs, laid loosely in the burrows of the bees, hatch in June, but our creatures did not substantiate his statement that the young are extremely active. 

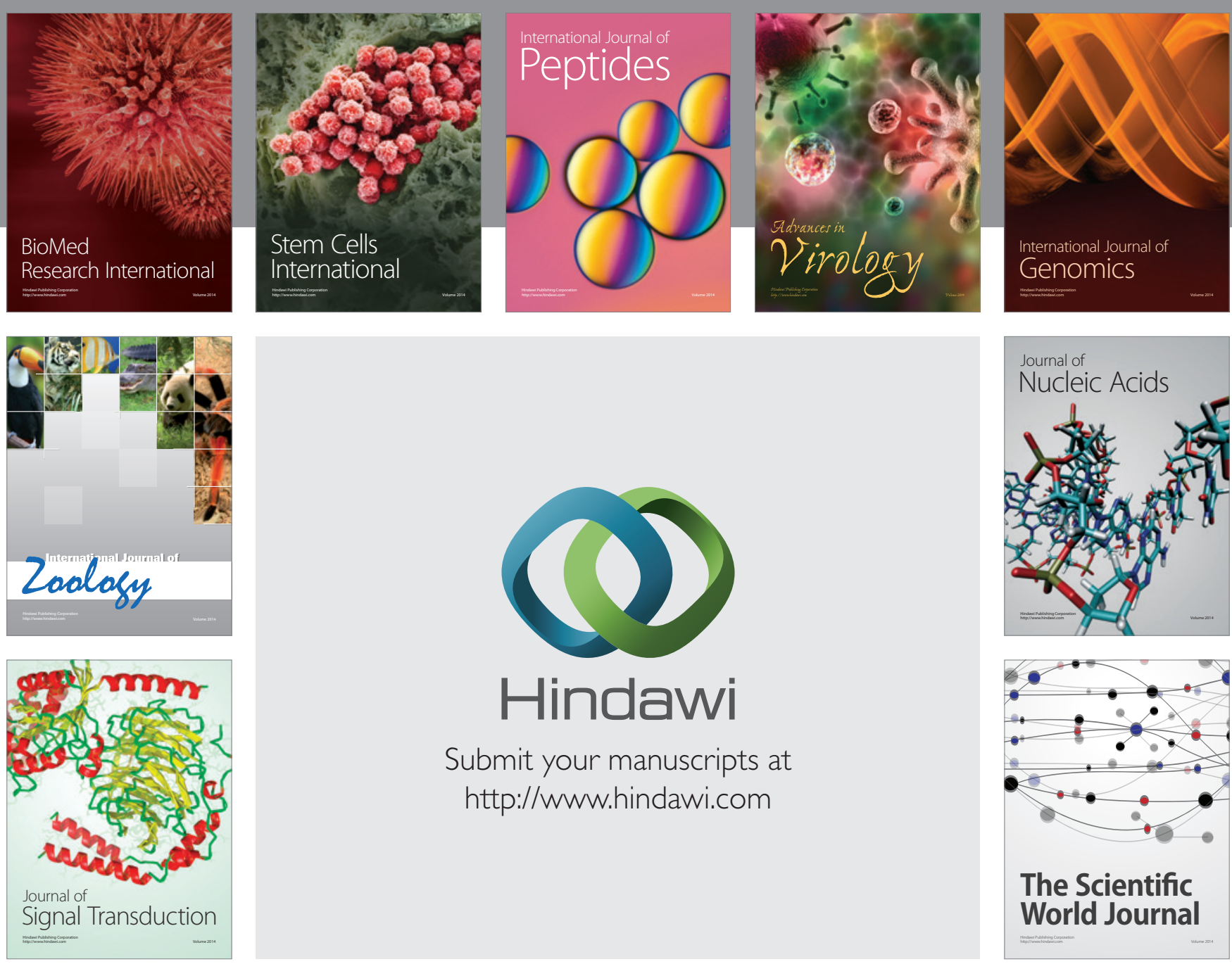

Submit your manuscripts at

http://www.hindawi.com
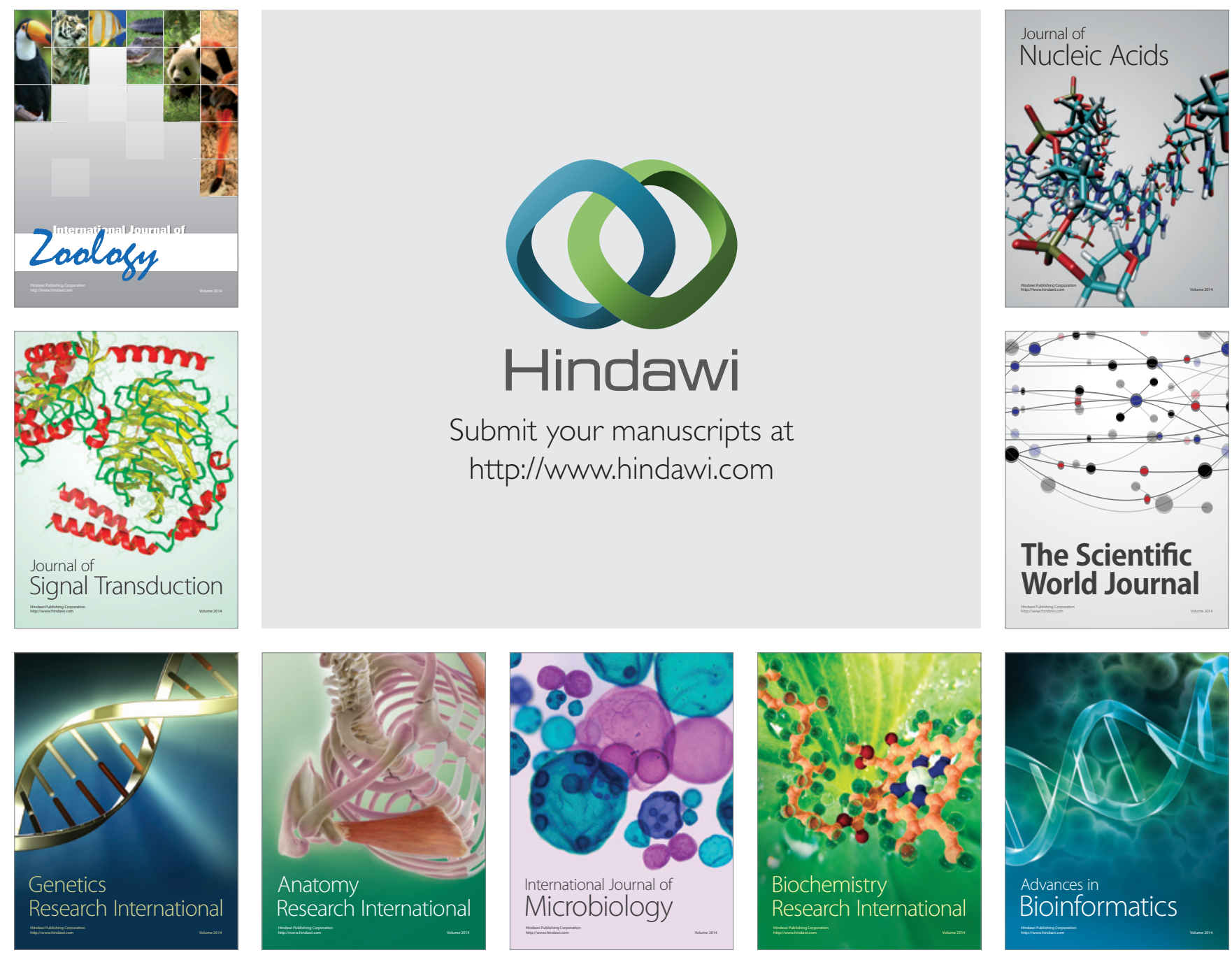

The Scientific World Journal
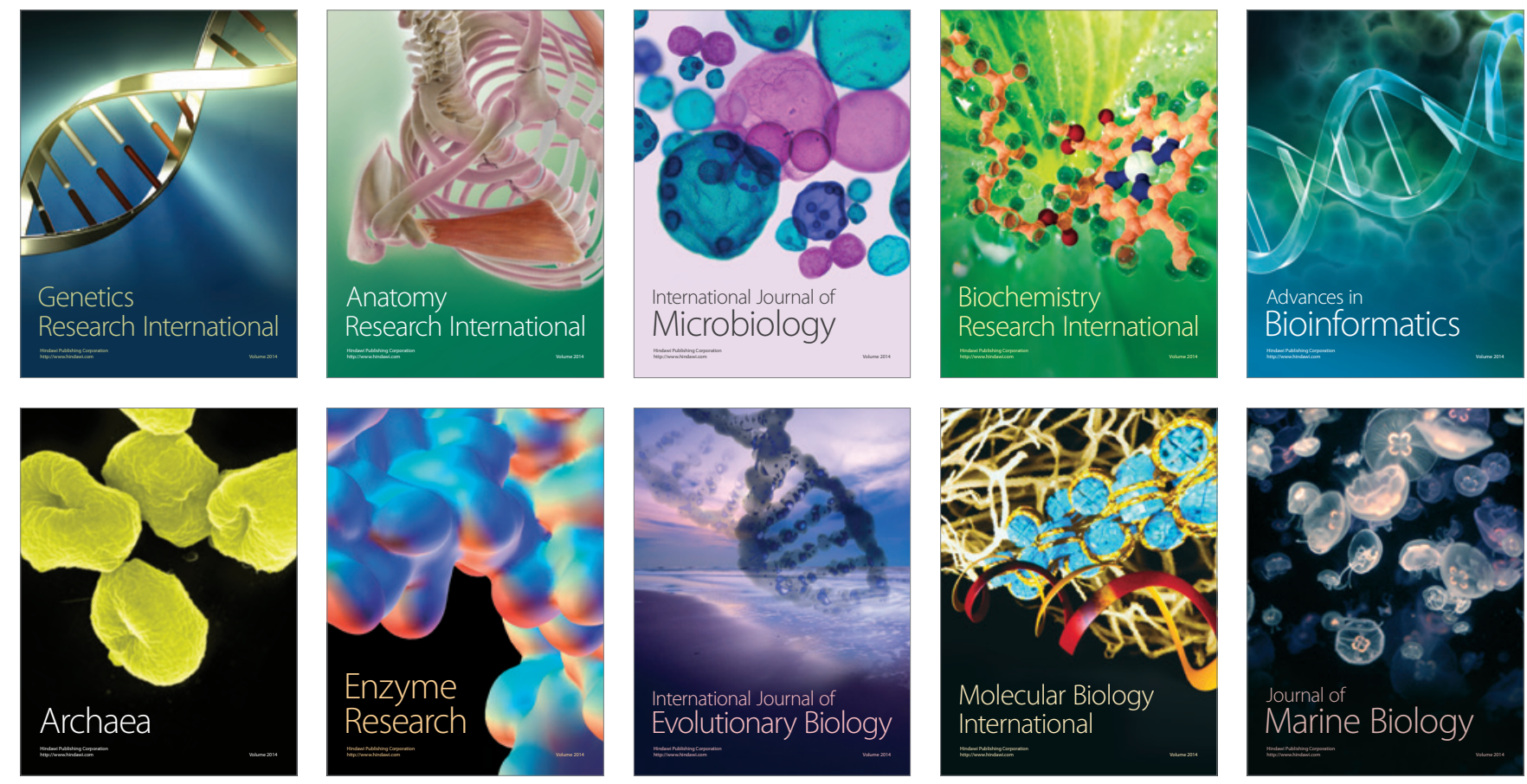